
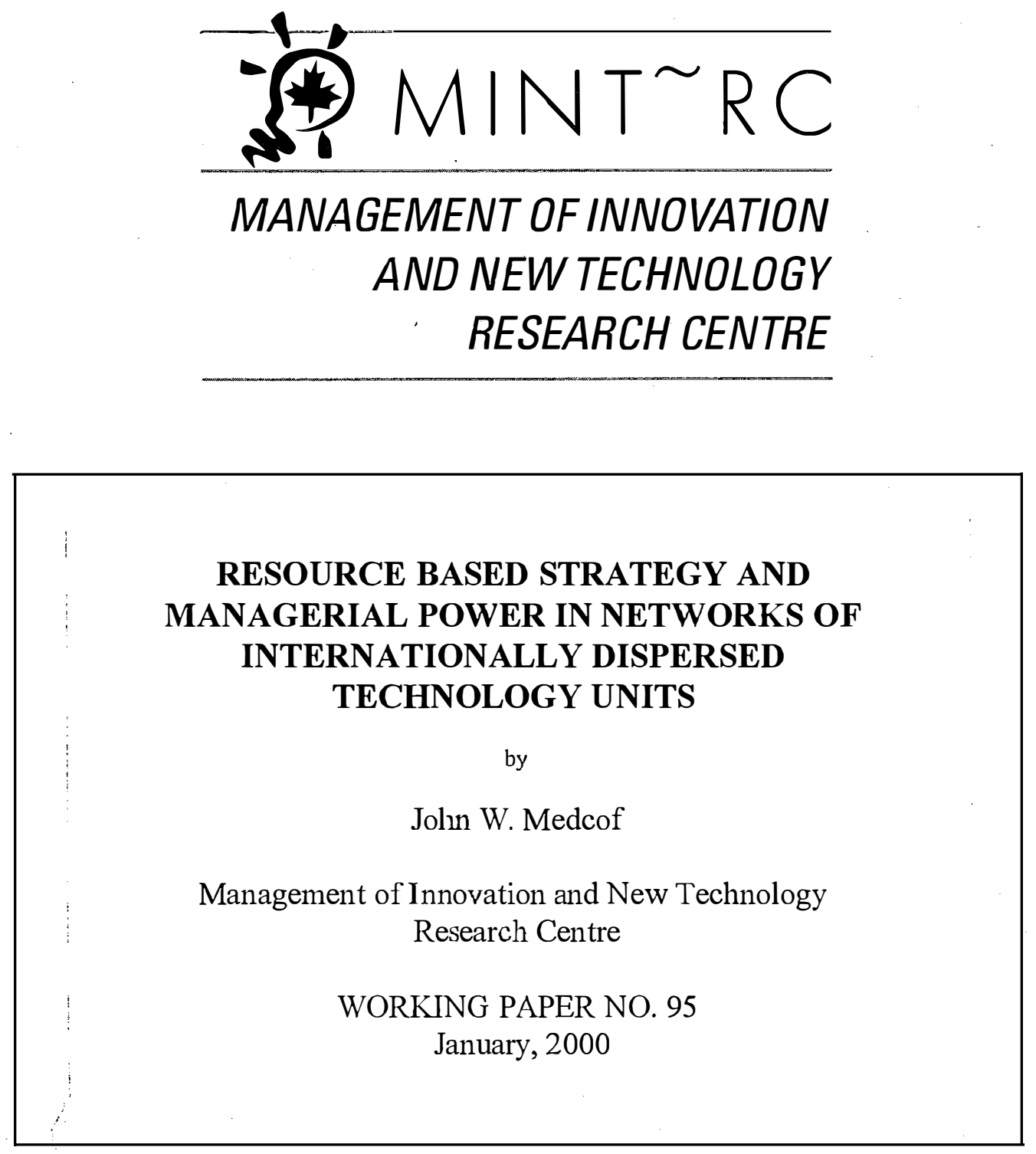

Innis

HD

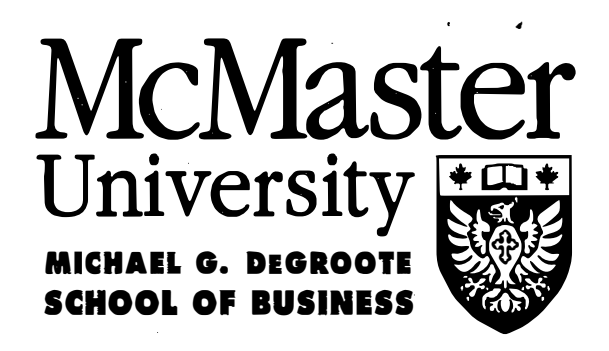

45

.W657

no.95 


\title{
RESOURCE BASED STRATEGY AND MANAGERIAL POWER IN NETWORKS OF INTERNATIONALLY DISPERSED TECHNOLOGY UNITS
}

\author{
by \\ John W. Medcof \\ Management of Innovation and New Technology \\ Research Centre \\ WORKING PAPER NO. 95 \\ January, 2000
}

The Working Paper series is intended as a means whereby a researcher may communicate his or her thoughts and findings to interested readers for their comments. The paper should be considered preliminary in nature and may require substantial revision. Accordingly, this Working Paper should not be quoted nor the data referred to without the written consent of the author. Your comments and suggestions are welcome and should be directed to the author. 


\title{
RESOURCE BASED STRATEGY AND MANAGERIAL POWER IN NETWORKS OF \\ INTERNATIONALLY DISPERSED TECHNOLOGY UNITS
}

\author{
John W. Medcof \\ The Michael G. DeGroote School of Business \\ McMaster University \\ Hamilton, ON, Canada L8S 4M4
}

Phone (905) 525-9140 X27434: Fax (905) 521-8995: E-mail medcof@mcmaster.ca 


\begin{abstract}
Attempts to resolve control issues in networks of internationally dispersed technology units using managerial techniques such as increased communication and/or the application of hierarchical control have had limited success because the control issues are rooted in the strategy of the firm. In this paper a linking of the Resource Based View of the firm, Resource Dependency Theory and the Vroom-Yetton model of leadership is used to show that when important technical resources are located offshore for strategic reasons, resource-based power goes with them. The extra-national technology units that embody those resources should be managed with methods that respect that power shift. Theoretical, empirical and managerial implications are drawn from this analysis
\end{abstract}




\section{RESOURCE BASED STRATEGY AND MANAGERIAL POWER}

\section{IN NETWORKS OF}

\section{INTERNATIONALLY DISPERSED TECHNOLOGY UNITS}

Many transnational firms now locate significant portions of their R\&D (technology) work outside their home countries and consequently must manage networks of internationally dispersed technology units (Chiesa, 1996a, b; Coughlan \& Brady, 1996; Dalton and Serapio, 1995; Florida, 1997; Gates, 1995; Granstrand, Hakanson and Sjolander, 1992; Kuemmerle, 1997; Medcof, 1997; Pearce \& Singh, 1992a, b; Penner-Hahn, 1998; Rhyne and Teagarden, 1995; Zander, 1997). Those extra-national technology units perform a number of functions running the gamut from the support of offshore marketing and manufacturing activities to the appropriation of cutting edge and/or cost effective technological resources located at extra-national sites (Albertini and Butler, 1995; Bartlett \& Ghoshal, 1990; Granstrand, et al, 1992; Hakanson, 1990; Kuemmerle, 1997; Malnight, 1995; Ohba, 1996)

When the strategic question of whether to locate technical work off shore is considered, the issue of control is an important concern (Granstrand et al, 1992). Technology work at remote locations is more difficult to control than that located close to home, and the dangers of duplication of work by different sites, drift away from strategic focus, and the leakage of proprietary technology are all increased. Strategy makers must weigh these and other risks against whatever the positives may be. Unfortunately, the literature on power and control in networks of internationally dispersed technology units, although it clearly demonstrates the importance of such issues to managers, provides no consensus concerning best practice (Asakawa, 1996; Bartlett \& Ghoshal, 1990; Pearce \& Singh, 1992a, b; Behrman \& Fischer 1980; 
Brockhoff and Schmaul, 1996; Buckley \& Brooke, 1992; Cheng, 1994; De Meyer \& Mizushima, 1989; Nobel \& Birkinshaw, 1998; Stock, Greis and Dibner, 1996). The solutions proposed to the problem of control usually focus on managerial and operational approaches. For example, some authors propose that control can be maintained by increased communication between the off shore units and home base (De Meyer and Mizushima, 1989; Granstrand et al, 1992). Frequent communication purportedly allows headquarters to better monitor the activities of far-flung units and to take corrective interventions in a timely manner. Other authors report that the exertion of authority is commonly used in an attempt to maintain control (eg. Asakawa, 1996), typically by providing rules, procedures and the requirement that important decisions be made at headquarters. Although these approaches are not without their virtues, they do have their problems, such as the destructive friction they can create within the organization (Asakawa, 1996). There is also evidence that approaches to control vary over time (eg. Malnight, 1996) and recently there has been a trend among some firms to reassert more central control, although significant decentralization is still present (Gassman and von Zedtwitz, 1998).

This stream of research is also characterized by a lack of theoretical integration. Most of the organizing constructs are primarily descriptive and/or based upon management practice. Typically, the constructs are derived from the questionnaire and interview responses of managers. There has been no concerted attempt to build theory with constructs that go much beyond these practical considerations.

It will be argued in this paper that the control issues described above are ultimately rooted in strategy. Once a particular strategic course is adopted, certain power dynamics are inevitably set into play that may be ameliorated by improvements in communication and the exertion of 
hierarchical control, but cannot really be resolved. To explain the strategic roots of these power dynamics, and the managerial issues they engender, this paper will draw concepts from three theories: the Resource Based View of the firm (Barney, 1991; Teece, Pisano \& Shuen, 1997); Resource Dependence Theory (Cool \& Henderson, 1998; Harpaz \& Meshoulman, 1997; Inkpen \& Beami sh, 1997; Oliver, 1991; Pfeffer \& Salancik, 1978; Yan \& Gray, 1994), and the VroomYetton model of leadership and decision making (Field \& House, 1990; Pasewark \& Strawser, 1994; Vroom \& Jago, 1988; Vroom \& Yetton, 1973). One outcome of this theoretical integration will be prescriptions about how strategically important extra-national units should be managed, and explanations as to why they should be managed differently from units with little strategic importance. In essence, this paper will build theoretical links among strategy, power and management in transnational technology networks, and generate a set of theory-based prescriptions for practising managers. This should help ameliorate the two major difficulties in this body of literature noted above, the lack of integrating theoretical models and the lack of consensus about best practice.

\section{Heterogeneity among Extra-National Technology Units}

Empirical studies over the last many years have demonstrated that extra-national technology units serve a number of purposes and there have been a number of attempts to classify them using various criteria (Behrman \& Fischer, 1980; Cheng, 1994; Cordell, 1973; Hakanson \& Nobel, 1993 a, b; Hewitt, 1980; Hood and Young, 1982; Medcof, 1997; Nicholson, 1994; Pearce \& Singh, 1992 a, b; and Ronstadt, 1977, 1978). For example, Medcof (1997) developed a classification that captured the essence of many previous taxonomies by proposing that units could be classified into eight categories based upon the technical activities they perform and the 
geographical areas over which they have collaborative relationships (Table 1). For example, Local Marketing Support Units are technology units which support marketing activities in a single country through such activities as providing technical assistance to customers and helping with incremental modifications to products for local markets. In contrast, International Research Units engage in basic research and collaborate with other research units spread across a number of countries. There is also a tradition of classifying overseas technology units into two broad groups (Archibugi and Michie, 1995; Chiesa, 1996a; Florida, 1997; Granstrand et al, 1992; and Kuemmerle, 1997). For example, Kuemmerle (1997) has suggested that extra-national technology units engage in two general categories of activities. Those engaged in home-baseaugmenting activities appropriate marketing and scientific knowledge that is available at offshore sites for the firm's present or future use. Those engaged in home-base-exploiting activities use the firm's current technical capabilities to support operations such as marketing and manufacturing at home or abroad.

Please insert Table 1 approximately here

Classifications of overseas technology units such as those of Medcof (1997) and Kuemmerle (1997) certainly bring increased coherence to this area of study, but they remain functional and practical classifications that lack attachments to more fundamental theoretical concepts. In short, they make an important contribution to our understanding and they are very probably useful in practical management discussions, but they have, as yet, not taken us to deeper levels of understanding. We will now show that a deeper level of understanding for this area of study can 
be provided by the Resource Based View of the firm.

The Resource Based View (RBV) of the firm (Amit and Shoemaker, 1993; Barney, 1991; Dierickx and Cool, 1989; Peteraf, 1993; Rumelt, 1984; Teece et al, 1997; Wernerfelt, 1984, 1995) postulates that sustained competitive advantage comes from having resources that create value in the marketplace and are unique. Although various scholars develop this theme in different ways, and develop somewhat different implications from it, they all agree that value and uniqueness are the basis for strategic importance. Barney (1991), one of the leading proponents of the approach, states that the value of a resource depends upon its efficiency and effectiveness (ie., its role in exploiting opportunities and/or neutralizing threats). Barney says that uniqueness derives from being rare (at most, only a few other firms have the resource), having imperfect imitability (other firms cannot imitate or acquire it) and being non-substitutable (there are no strategically equivalent resources available to other firms).

The RBV has been applied to transnational technology strategy by a number of writers (Cheng, 1998; Duysters and Hagedoorn, 1998; Florida, 1997; Henderson and Cockburn, 1994; Kuemmerle, 1998; Medcof, 1998; Methe and Yoshihara, 1998; Toyama and Methe, 1997). The basic proposition is that organizations locate technology units overseas in order to appropriate the valuable and unique technology resources which are available at the extra-national locations but not in the home country, at least not at the same cost advantage. For example, International Development Units collaborate with each other across national boundaries to create new products which will be introduced into large international markets. Very often theindividual International Development Units embody technical capabilities that are unique in the firm, and in the world, and are the key to developing market-leading products. These studies and interpretations have 
focussed almost entirely upon the prospect of accessing highly unique and valuable (strategically important) resources at extra-national sites. Empirical studies generally support this reasoning.

However, the empirical studies discussed above have identified many and varied types of extra-national technology units (Behrman \& Fischer, 1980; Cheng, 1994; Cordell, 1973; Hakanson \& Nobel, 1993 a b; Hewitt, 1980; Hood and Young, 1982; Medcof, 1997; Nicholson, 1994; Pearce \& Singh, 1992 a, b; and Ronstadt, 1977, 1978) and suggest that not all overseas technology units have high value and uniqueness. For example, Local Marketing Support Units (Medcof, 1997) generally help customers in the local market and tweak products for sale in the local market. Although every market is unique in some ways, by and large the roles of these units are quite similar regardless of where they are. They provide the generic technical support that must be provided in any technology-driven market and, therefore, are not really unique within their own firms or in the industry. Neither are they very valuable. These units are located within the marketing function and they make a contribution that is no more valuable than other marketing activities, such as advertising and direct sales. In short, most Local Marketing Support Units do not play strategically important roles. The same can be said for most Local Manufacturing Support Units. They usually adapt technology developed at home to a particular overseas context and help maintain its function once it is operative. Their work is embedded in the manufacturing process and is much the same everywhere. In short, many extra-national technology units embody functions that are not very important strategically because what they do is neither very unique nor very valuable, as is suggested in the following proposition. 
Proposition 1: Extra-national technology units are heterogenous with respect to the uniqueness and value of the resources they embody and, therefore, in their degree of strategic importance.

Various authors have anticipated this idea by ordering extra-national technology units (and/or their technical work) along continua of various kinds. For example, Taggart (1998) suggested a dimension of "R\&D complexity" with customer support as the least complex and the production of new technology (research) as the most complex. Nobel and Birkinshaw (1998) suggested a three-category typology, based primarily on the work of Pearce (1989), which has "local adaptor" as the least strategic important and "international creator" as the most. However, these earlier continua are not based upon the concept of strategic importance or, if they are, have only tenuous links to a theoretical base. The explicitly drawn relationship between technology unit types and the theoretical concepts of uniqueness and value developed here advances our understanding in this respect and, as we shall see, enables clear links to other theories. The first such link will be to a theory of organizational power.

\section{Value, Uniqueness and Organizational Power}

Now that it is established that there is heterogeneity in the value and uniqueness of resources embodied in extra-national technology units, we can turn to the implications of this for power relationships within the organization. The theoretical link between the RBV and organizational power will be made using Resource Dependency Theory (Pfeffer \& Salancik, 1978). Resource Dependency Theory (RDT), although originally formulated some years ago (Pfeffer \& Salancik, 1978), has recently been found useful by a number of authors (Cool \& Henderson, 1998; Harpaz \& Meshoulman, 1997; Inkpen \& Beamish, 1997; Oliver, 1991; Yan \& Gray, 1994). 
RDT states that the amount of power that an organization has depends upon the resource dependency relationships it has with other organizations. If a focal organization is highly dependent upon another organization for an important resource (a particular input to its manufacturing process, for example), that other organization will have power over the focal organization. Although RDT was originally formulated to discuss the relationship between organizations and entities in their environments; such as customers, suppliers, governments and regulators; the theory has been found to be readily applicable to the relationships among units within organizations (e.g. Harpaz \& Meshoulman, 1997). Here we will consider dependency in the relationships between a firm's headquarters in the home country and its extra-national technology units.

$\mathrm{RDT}$ proposes that three factors are critical in determining the dependence of one organizational unit upon another and therefore their relative power.

1. Resource Importance. The more important the resources controlled by a unit, the more other units will be dependent upon it, and the greater will be its power over those other units.

2. Alternatives. The fewer the alternative sources there are for a resource controlled by a unit, the more other units will be dependent upon it for the resource, and the greater will be the power of that unit.

3. Discretion. The greater the degree of unfettered discretion that a unit has in the deployment of a resource, the greater will be others' dependence on it, and the greater will be its power. 
Maximum dependency, and therefore maximum power, occur when one unit has unfettered discretion over a resource of high importance to another unit, and there are no alternative sources.

RDT can be theoretically connected to the RBV by considering the close conceptual link between certain of their concepts. The RBV holds that sustained competitive advantage comes from having resources of sustained uniqueness and value. The concept of value in the RBV is very close in meaning to that of importance in RDT. For example, a resource has high value if it is the basis for the firm's success in a particular, large market. In that case it can be said that the resource is important to the firm. The more the resource is the basis for success (value) the more the firm depends upon it and the more important it is. The organizational unit which embodies that important resource thus has a basis for organizational power. The concept of uniqueness from the RBV is very close in meaning to the concept of alternatives in RDT. If a resource is unique to a particular organizational unit, there is no alternative source for it, and the resource will be a basis for organizational power. These considerations lead to two more propositions.

Proposition 2: $\quad$ The greater the value (importance) to an organization of the resources embodied in a particular organizational unit, the greater will be the dependency of the organization upon that unit, and the greater will be the power of that unit within the organization.

Proposition 3: The greater the uniqueness of a resource embodied in an organizational unit, the greater will be the dependency of the organization upon that unit, and the greater will be the power of that unit within the organization. These two propositions, when combined with the basic premises of the RBV concerning value, 
uniqueness and strategic importance; yield another.

Proposition 4: $\quad$ Organizational units have power directly proportional to the strategic importance of the resources they embody.

\section{Variation in Management Approach}

It will now be shown that the amount of power embodied in an organizational unit (and by implication, its strategic importance) determines how it can best be managed. This will be done by examining in more detail the nature of the dependence that results from the uniqueness and value of extra-national units. Uniqueness and value can create a number of different kinds of dependencies with varied implications for different aspects of organizational function. Here we will explore those aspects of dependency that are most relevant to the activity of managing. This will allow us to be theoretically specific about which management approaches are most appropriate for units with different degrees of strategic importance. We are taking this approach because we are faced with a conceptual gap between the concept of dependence at the strategic level, as we have already discussed it, and dependence as it must be understood in the context of management. What we will do here is to provide a conceptual bridge between those two facets of dependence in order to link the realms of strategy and management. As will be seen, that theoretical link will be developed using the Vroom-Yetton model of leadership (Vroom \& Jago, 1988; Vroom \& Yetton, 1973).

The premise that different kinds of extra-national technology units should be managed in different ways is not new (Chiesa, 1996a; Nobel and Birkinshaw, 1998; Reger, 1999; Stock et al, 1996). However, this idea is usually based upon the experience of managers as reflected in the empirical studies which have gathered their perceptions. No fundamental theoretical basis has 
been offered for this premise. Here, we will develop a theoretical explanation, and that explanation will be used to generate a number of prescriptions for best practice.

\section{The Vroom-Yetton Model}

The Vroom-Yetton model (Field \& House, 1990; Pasewark \& Strawser, 1994; Vroom \& Jago, 1988; Vroom \& Yetton, 1973) states that there is a variety of ways to make decisions and that a manager should choose the way that is most appropriate given the nature of the problem to be solved and the context in which the decision is to be made. The model provides a number of criteria for deciding which decision making mode to adopt.

Turning first to the available decision making modes, the model proposes a spectrum of modes that vary in the degree to which subordinates are involved in the decision making process.

Autocratic The leader makes the decision all alone

Consultative The leader makes the decision after consulting with subordinates to collect information and perspectives

Inclusive The leader involves subordinates in a process of decision-making by consensus.

Although these three are the core types of decision making, the model includes variants on each. We will use just the three core types in our discussion here. The original statement of the model uses the term "group" to refer to the third decision making mode. Here the term "inclusive" is used since it captures better the essence of that mode.

The Vroom-Yetton model proposes five criteria to be considered when deciding which decision mode to use. These include the importance of the technical quality of the decision itself, the commitment to the decision of those who must implement it, its timeliness (is the decision 
made quickly enough to be implemented in the window of opportunity for effective intervention), the cost of the human capital used to make the decision, and the degree to which the decision process provides a learning opportunity for members of the organization. Some of these five factors are more concerned with the temporal and organizational context of the decision than with the quality of the decision itself.

The model suggests that, of the five criteria, two are of overwhelming importance relative to the others, namely, the technical quality of the decision and the effectiveness of its implementation. The technical quality of the decision depends upon having the information necessary to make it, and upon structuring the problem effectively in the first place so that the decision is appropriately framed to solve the problem it is intended to solve. The effectiveness of the implementation depends upon having people with the abilities and motivation necessary to execute the decision. To preserve the clarity of our primary theoretical thrust, we will carry forward our argument here using only these two most fundamental criteria.

In broad terms, the Vroom-Yetton model prescribes that: if the leader is able to frame the problem effectively alone; has all the information necessary to make the decision; and knows that the subordinates will effectively carry out the decision, even if they do not participate in its making; then it is most effective for the leader to make the decision autocratically. In contrast, if subordinates have some of the understanding and knowledge needed to frame and make the decision, and are likely to implement it effectively even if they are not involved in a consensus building process, the consultative approach will be most effective. Under it, the leader will get from the subordinates whatever is lacking then make the decision alone. Finally, if subordinates have knowledge and understanding necessary to frame and make the decision, and are unlikely to 
implement it effectively unless they are involved in a consensus-based process for making the decision, then the inclusive approach is best.

The essence of this model is that the optimal decision-making mode is contingent upon whether the leader is dependent upon others for information, problem framing capabilities, and/or commitment in implementation. Although the full model involves many nuances built upon these fundamentals, these essentials are all that are needed to draw the link between strategy and management.

Although the Vroom-Yetton model focuses on individual decisions and the face-to-face leader/group situation, its general conceptual framework can be applied beyond that particular setting. The methods of management and control of an organization are essentially the ongoing practices for making decisions in that organization since management is a process of making decisions and coordinating their execution. It is also likely that most organizations use all of the Vroom-Yetton decision modes to some extent but have a bias for using some more than others. The mode that is predominantly used sets the tone for the organization. Organizational structure is, essentially, the enactment of the usual decision making practices of the organization. If the managers in an organization customarily make their decisions using the autocratic mode, the organization will be said to authoritarian and centralized. If the managers typically use the inclusive approach, the structure will be said to be decentralized and participative.

The Vroom-Yetton model can, therefore, be applied to the case of transnational technology management. The headquarters unit in the home country must decide upon the degree to which it will involve the members of extra-national units in its decision making processes. Will decision making be autocratic, consultative of inclusive with respect to those units? The answer to that 
question will depend upon the degree of uniqueness and value of the resources embodied in the extra-national units.

If the resources of an extra-national technology unit are highly unique, it implies that the members of that unit are the only ones within the organization who have complete and deep information about the technology. It also implies that the members of that unit will also be essential in helping to frame problems which involve that technology. In other words, the headquarters unit will be dependent upon that unit for its unique information and problem framing capabilities. This suggests that headquarters should involve the unit to at least the consultative level when making important decisions which involve a consideration of that technology. Once the unit's problem framing skills and information has been brought to bear through consultation, headquarters will be able to make the decision.

Proposition 5: Extra-national technology units which embody technology resources that are of high strategic importance (unique and valuable) should be included in decisions concerning that technology to at least the level of consultation.

However, many of the decisions involving the technologies embodied in extra-national units involve the combination of several technologies, which are not all embedded in one unit (Zander, 1997). Framing and making these multi- technology decisions requires inputs from all of the units which embody the technologies in question. Furthermore, the framing and decision making can typically be done effectively only through a collaborative interaction of those units, given the complexity of the problems. Headquarters alone is not capable of integrating all of the relevant considerations since it lacks the necessary expertise in the relevant multiple technologies. This 
suggests that the problem will only truly be solved and the best decision facilitated when all the units which understand the technologies involved have discussed it with each other and agreed that all the important considerations have been addressed. This leads to the next proposition. Proposition 6: $\quad$ When decisions must be made which involve multiple strategically important technologies embedded in multiple technology units, those decisions should be made by an inclusive decision making process.

There is considerable evidence that International Research Units and International Development Units operate under the conditions referred to in Proposition 6 (Granstrand et al, 1992; Nobel and Birkinshaw, 1998; Pearce and Singh, 1992a, b). They are strategically important since they are involved in the creation of unique, multi-technology products intended for sale in large markets which span a number of countries (high value).

Proposition 7: $\quad$ International Research Units and International Development Units should be managed by headquarters through inclusive decision making processes.

But decision implementation is also an important consideration in this context. A decision taken concerning a technology will usually require experts in that technology for its implementation. Only those experts have the knowledge and skills necessary for execution. So headquarters is also dependent upon the extra-national units for the execution of decisions involving the strategically important technologies they embody. Organizational culture influences the degree to which members of extra-national units are inclined to participate in decision execution. If culture has engendered a strong sense of commitment to the organization, members will enthusiastically tackle the job of implementation, regardless of how the decision was made. At the opposite end of the scale are organizations whose members are extremely 
difficult to mobilize, particularly if they believe the decision was a poor one or was arrived at by an inappropriate method (usually these two perceptions are closely linked). Most organizations fall somewhere on the continuum between these two extremes. The Vroom-Yetton model posits that participation in consensus-based decision making increases the probability that organizational members will enthusiastically implement a decision. This implies the next proposition.

Proposition 8: $\quad$ The need for inclusive decision making processes is increased for extranational technology units when the commitment of unit members to a solution is in question.

The logic developed above has focused upon strategically important technology units but our earlier discussion showed that extra-national technology units are heterogenous with respect to uniqueness and value. So a corresponding set of propositions can be developed for extranational technology units of low strategic importance.

Proposition 9: The lower the strategic importance of the technology embodied in an extra-national unit, the greater the probability that it can be effectively managed through processes that involve little or no consultation with the headquarters unit.

The earlier discussion of the low strategic importance of Local Marketing Support Units and Local Manufacturing Support Units, and of decision commitment, suggest the following. Proposition 10: $\quad$ Local Marketing Support Units and Local Manufacturing Support Units can be effectively managed through processes that involve little or no consultation with the headquarters unit. 
Proposition 11: The greater the degree to which the commitment to decision implementation of members of Local Marketing Support Units and Local Manufacturing Support Units is an issue, the greater the need to use consultative and perhaps inclusive decision making processes.

This completes the alignment of the literature on different types of extra-national technology units with the RBV, RDT and the Vroom-Yetton model. We can capture the essence of that alignment by considering the extreme cases. Local Marketing and Manufacturing Support Units embody resources of low value and uniqueness and therefore have low power within the organization, given that the organization is not highly dependent upon them. Consequently, they can be managed by home headquarters through relatively autocratic management modes. At the other extreme, International Research units have high strategic importance based upon high uniqueness and value, so they have high power in the organization which is highly dependent upon them. Consequently they should be managed by home headquarters by relatively inclusive management techniques.

\section{Empirical Evidence}

Given that the above propositions are predominantly prescriptive, we might ask if transnational firms actually practice them. There is evidence that at least some management teams deploy power as the propositions suggest. For example, Nobel and Birkinshaw (1998), in their study of Swedish multinationals, i dentified three different kinds of overseas technology units and found that they are controlled by headquarters through different mechanisms. One type, "local adaptors", whose mandate is to adapt existing products and processes to local demands (low strategic importance), are managed primarily by formalization, a form of 
autocratic control which involves the provision of rules and procedures by headquarters. Another kind of unit, "international creators", which are primarily involved in research and development at the international level (high strategic importance), are controlled primarily through socialization, which involves frequent inter-unit visits and the exchange of personnel, implying inclusion in decision making processes. Corporate headquarters appears to be appropriately managing them by collaborative mechanisms involving rich communication links. These matchings of strategic importance and control/communication modes seem, on the face of it, to be consistent with the prescriptions developed above.

Taggart (1998) compared extra-national manufacturing subsidiaries which were increasing the complexity of their technology work to those which were decreasing the complexity. His continuum of "R\&D Complexity" roughly parallels that for strategic importance presented here, but is based upon somewhat different premises. He found that subsidiaries which were taking on increasingly complex technical work (increasing strategic importance) were moving to less autocratic control by headquarters while those moving to less complex technical work were moving towards more autocratic methods of management by headquarters. Although not a direct test, this is consistent with the propositions developed above.

Brockhoff and Schmaul (1996) also found evidence of firms following the prescriptions developed here, in their study of German multinationals. Their data show that some overseas technology units are controlled, not by a headquarters technology unit, but by other overseas units of the firm which are not primarily concerned with R\&D. For example, an extra-national marketing unit might house an extra-national technology unit. We can surmise that these technology units are marketing support units doing work of low value and uniqueness, as 
discussed above. Brockhoff and Schmaul's data show that these units have little autonomy, which is consistent with Proposition 10. Brockhoff and Schmaul linked these function and control contingencies to performance, an important element of their research which should be pursued in future empirical studies.

Asakawa (1996), however, reported cases involving less adroit deployment of power. He found that some of the Japanese companies in his sample increased their hierarchical authority over offshore units that appeared to be acquiring too much autonomy. Increased autonomycontrol tension resulted. It was in areas of high strategic importance, such as intellectual property and research initiatives, that such tensions were most likely to occur. This is consistent with Proposition 6 which suggests that inclusive rather than autocratic processes should be used with units that embody strategically important technologies.

The empirical evidence just reviewed suggests that the theoretically based prescriptions developed here are followed by at least some management teams. However, this evidence is, at best, suggestive, since none of these studies was designed specifically to test these propositions. Since many of these propositions are prescriptive, direct tests of them should include explicit measures of organizational performance. Direct tests might evaluate the proposition that technology units which do strategically important work will have more resource-based power than those which do less important work. This could be tested using questionnaires which gather senior managers' perceptions of the strategic importance of the work of technology units, and correlating those with measures of the resource-based power of those units. Measures of resource-based power can be found in the RDT literature. Measures of hierarchical management methods, such as those used by Nobel and Birkinshaw (1998), and measures of organizational 
conflict could also be applied to test whether hierarchical management methods, when inappropriately applied to organizational units that are strong on resource-based power, create excessive organizational conflict.

\section{Theoretical and Methodological Extensions}

The development of the propositions in this paper has relied upon Medcof's (1997) classification of technology unit types. That classification is based upon a long tradition of empirical research which stresses the function and the geographic region of collaboration of extra-national technology units. This descriptive classification has proven useful in developing the theoretical points made in this paper, but a closer examination of its limitations suggests that a classification more systematically related to the theoretical concepts of the RBV would be even more useful in future research and theoretical development.

The limitations of this traditional approach and the greater potential of a theoretically based approach can be exemplified as follows. The argument made above that International Research Units are more strategically important than Local Marketing Support Units is plausible given the data we currently have available. That argument is sufficient to make the case for the general theoretical approach being proposed here. However, an attempt to do a more fine-grained analysis of the strategic importance of various kinds of units shows the limitations and ambiguities of the descriptive, non-theoretical approach. For example, if we ask whether International Research Units are more strategically important than International Development Units we soon find that a clear answer is not available. Development units do work that is closer to commercialization than that of research units, does that mean that development units are more strategically important than research units? The potential markets for research work are 
generally larger than those of development work, given that the former attempts to develop technological knowledge with very long term and very broad market potential, while the latter focuses on products whose markets are clearly bounded in time and space. Does this mean that research is more strategically important than development? Clearly, the relative strategic importance of research and development units is not easy to disentangle on the basis of their functions and geographical areas of collaboration, indicating the limitations of the traditional classifications which must be overcome if further theoretical development is to be pursued. The analysis performed here shows that the RBV concepts of value and uniqueness have some promise in this regard and should be more closely investigated to develop a more refined, theorybased, classification system for extra-national technology units. Such a system would not only provide more conceptual clarity with respect to strategic importance, it would also have the advantage of being theoretically linked to RDT and the Vroom-Yetton model.

Although the recommendation here is to develop a more rigorous method for classifying extranational technology units along a spectrum of strategic importance using the concepts of value and uniqueness, it should be borne in mind that this task will not be an easy one. The definition and empirical measurement of value and uniqueness are tasks which RBV theorists have not yet accomplished in an entirely satisfactory manner, and any progress on it through studies of extranational technology units could provide a contribution to the broader enterprise being pursued by RBV theorists and empiricists.

Turning to another area of theoretical concern, in recent years there has been a movement towards developing strategic approaches to technology management and to integrating technology strategy with the strategy of the firm (Chester, 1994; Kenney \& Florida, 1994; 
Mitchell, 1992; Pearson, Brockhoff and von Boehmer, 1993; Ransley and Rogers, 1994; Rhyne and Teagarden, 1995; Schilling, 1998). Evidence indicates that such integration is achievable and that it contributes to firm performance, at least in technology-driven industries (Dussauge, Hart and Ramanantsoa, 1987). This paper has contributed to this larger movement by showing that a theory of strategy, the RBV, is applicable to transnational technology management in an explicit way that can be drawn out into implications for management.

There have also been calls to make more use of organizational theory and organizational behavior in the study of technology management and international business. Cusumano and Elenkov (1994) propose that more effective integration of the management and strategy literatures will enable us to understand international technology management better. Doz and Prahalad (1991) propose the application of more organization theory in the study of diversified multinational firms. This paper is very much in the spirit of those proposals in its linking of the RBV, RDT and the Vroom-Yetton model in the understanding of transnational technology management.

\section{Implications for Managers}

In the introduction to this paper the attempts of managers to solve control problems using authoritarian approaches and/or increased communication were mentioned and their limitations alluded to. Now that our theoretical analysis is complete we can better understand those limitations.

The propositions above suggest that attempts to solve control issues using authoritarian approaches are likely to have more success with some extra-national units than with others. Extra-national units of low strategic importance are more effectively managed by relatively 
autocratic means than are those of high strategic importance. Success with autocratic decision making modes in some quarters may partially explain the tendency to try and apply them in all situations, even when they are not appropriate.

The dangers of not using inclusive methods of management with extra-national units of high strategic importance are brought to the fore by the theoretical connection we have made above between strategic importance and power. As Proposition 4 suggests, units of high strategic importance have high power within their organizations. Recently it has been pointed out that powerful units are in a position to seriously disrupt the function of the organization as a whole if they are not given what they perceive to be appropriate roles in decision making (e.g. Oliver, 1991; Pearce, 1997). Because of the high dependency of the organization upon strategically important units, those units have considerable capacity for destructive countervailing activity.

Pearce (1997) focuses upon the cost of bargaining activities among powerful actors. When powerful parties disagree the transaction costs can be very high and dysfunctional. This is particularly so when the parties to the bargaining are beset by the kind of factionalism that can occur when they do not share the sense of common purpose that is sustained by consensual decision making.

Oliver (1991) provides an exhaustive list of actions that an organization or an organizational unit might take in response to authoritarian pressures from outside. Oliver's principle categories of responses are acquiescence, compromise, avoidance, defiance and manipulation. An extranational technology unit can choose among these response categories when its headquarters unit prevails upon it. Oliver proposes that the likelihood that a unit will resist such outside pressures will be a function of the power relationship between them. Rowley (1997) develops this theme 
even further. It follows that an extra-national technology unit will be more able to resist headquarters and engage in defiance and manipulation when it (the extra-national unit) has high power in the organization. This can be put in the form of two propositions.

Proposition 12: Extra-national technology units of high strategic importance are more likely to respond to unwanted authoritarian influence attempts from headquarters with defiance and manipulation than are extra-national units of low strategic importance.

Proposition 13: Extra-national technology units of low strategic importance are more likely to respond to unwanted authoritarian influence attempts from headquarters with acquiescence and compromise than are extra-national units of high strategic importance.

In short, the countervailing power of strategically important extra-national technology units enables them to disrupt organizational function in a variety of ways. Attempts to use authoritarian approaches to manage them are, therefore, fraught with danger.

This discussion of the countervailing power of strategically important extra-national technology units provides a point of contact between the theoretical developments in this paper and another very important body of theory, transaction cost economics (Williamson, 1975, 1985). The Vroom-Yetton model is an attempt to prescribe ways to make decisions more efficiently and effectively. One of its basic assumptions is that inclusive decision making is more expensive (cost of participant's time) than is consultative decision making, and consultative is more expensive than autocratic (independent of the issue of the quality of the decision). The VroomYetton model recommends the use of the least expensive decision making mode that is able to 
deliver the required level of decision quality. If we take the decision making activity to be a transaction, we see that the Vroom-Yetton model is fundamentally about transaction costs and that an underlying theme in the theoretical developments in this paper is the tradeoff between transaction costs and decision quality. For example, it is prescribed that autocratic methods (low transaction costs) are most effective when the extra-national units involved have little to contribute to decision (and implementation) quality. Inclusive methods (high transaction costs) are prescribed when the extra-national units involved have a great deal to contribute to decision and implementation quality, and failure to include them could lead to power struggles that drive transaction costs even higher. This line of reasoning, which might draw on some work that has already been done on transaction costs and transnational technology management (e.g. Crosier, 1998), holds promising theoretical possibilities, but it is beyond the scope of this paper to pursue them here.

The other often-mentioned approach to exerting control over overseas technology units, the use of communication, also has its problems, as revealed by the theoretical analysis presented above. Basic communication is simply the exchange of information and can be accomplished electronically or by traditional methods (Nobel and Birkinshaw, 1998). Simple transmission of information may be quite effective when authoritarian and consultative decision making processes are being used but inclusive decision making requires more. As stated in Proposition 6, when complex information is to be provided by multiple, strategically important and unique technology units, collaborative problem framing and commitment to the implementation of the solution have high importance. In such cases, inclusive methods of decision making are prescribed and communication merely for the transmission of information is not enough. 
This consideration of the inadequacy of autocracy and simple communication as control modes for networks of extra-national technology units brings us to the issue of power myopia among managers. It is not unusual to see academic and business writers who are addressing issues of control in transnational technology networks lauding the value of hierarchy and communication as solutions. We can now better appreciate that, although there is undoubtedly value in their analyses, they do not tell the whole story. The analysis here suggests that the most important reason for loss of control in such networks is the shift of resource-based power offshore when strategically important technical resources are located there. The failure of the literature to even mention this possibility, even though power and control are the focus of discussion, suggests a certain myopia on the part of managers and researchers alike.

The paper has outlined a classic case of the interaction of the social and economic subsystems of the organization. When strategically important resources are located overseas for reasons that involve efficiency (the overseas location is the lowest cost source or the only source of the technology) this action also changes the social structure of the organization, specifically, some power is shifted to the off shore locations. This action puts countervailing power in the hands of the managers in the offshore locations. Unless this situation is handled appropriately the off shore managers can use their countervailing power to resist and/or subvert the intentions of central headquarters. That resistance can take the form of protracted, divisive and acrimonious negotiations which can send transaction costs soaring. On the other hand, this paper suggests that the "proper" way to handle such situations is to manage with inclusive methods. But, as the Vroom-Yetton model suggests, inclusive methods involve higher transaction costs than consultative and autocratic methods. Consequently, management teams who locate important 
resources offshore for efficiency reasons should expect their transaction costs to rise, no matter how they handle it, thus eroding some, if not all, of the expected efficiencies. This is a case in which those who pursue strategies that appear, on the surface, to provide efficiencies, should beware that these actions can alter the organization's social system in ways that reduce efficiencies in unexpected ways.

This analysis suggests that if strategically important technical work is located overseas, resource-based power goes with it and this inevitable fact must be considered by strategic decision makers. Putting strategically important work offshore carries with it the necessity of managing that work with systems that respects the location of the resource-based power. An inclusive method of management is recommended over one which is hierarchically driven by the home office. If a management team is not prepared to manage with inclusive methods it should resist the temptation to locate strategically important technical work offshore. 


\section{References}

Albertini, S., \& Butler, J. (1995) R\&D networking in a pharmaceutical company: some implications for human resource management. $R \& D$ Management, 25(4), 377-393.

Amit, R. H., \& Shoemaker, P. J. H., (1993) Strategic assets and organizational rent. Strategic Management Journal, 14 (1): 33-46.

Archibugi, D., \& Michie, J., (1995) The globalization of technology: a new taxonomy. Cambridge Journal of Economics, 19, 121-140.

Asakawa, K., (1998) Evolving Linkage Mechanisms as Social Capital: Internationalization of $R \& D$ by Japanese $M N C$ 's. Working Paper \#56, Keio University Graduate School, of Business Administration.

Barney, J. B., (1991) Firm resources and sustained competitive advantage. Journal of Management, 17(1): 99-120.

Bartlett, C. A., \& Ghoshal, S., (1990) Managing innovation in the transnational corporation. In Bartlett, C. A., Doz, Y. L., \& Hedlund, G. (Eds.) Managing the Global Firm. New York: Routledge.

Behrman, J. N., \& Fischer, W. A. (1980) Overseas R\&D Activities of Transnational Companies. Cambridge, MA: Oelgeschlager, Gunn and Hain.

Brockhoff, K. K. L., \& Schmaul, B., (1996) “Organization, Autonomy, and Success of Internationally Dispersed R\&D Facilities." IEEE Transactions in Engineering Management, 43(1), 33-40.

Buckley, P. J., \& Brooke, M. Z., (1992) International Business Studies. Oxford, UK: Blackwell. 
Cheng, J. L. C. (1994) Managing innovation in US and Japanese overseas labs: The effects of corporate, scientific and local cultures on R\&D performance. Presented at the Annual Convention of the Academy of Management, Dallas, Texas.

Cheng, J. L. C., (1998) Multinational strategy, foreign R\&D investment, and innovation performance: a resource deployment perspective. Presented at The Academy of Management 1998 Meeting, San Diego.

Chester, A. N., (1994) “Aligning Technology with Business Strategy.” Research-Technology Management, Jan-Feb, 25-32.

Chiesa, V. (1996a) Managing the internationalization of R\&D activities. IEEE Transactions on Engineering Management, 43(1), 7-23.

Chiesa, V. (1996b) Strategies for global R\&D. Research-Technology Management, Sept.-Oct., 19-25.

Cool, K., and Henderson, J., (1998) Power and firm profitability in supply chains: French manufacturing industry in 1993. Strategic Management Journal, 19, 909-926.

Cordell, A. J. (1973) Innovation, the multinational corporation: Some implications for national science policy. Long Range Planning, Sept. 22-29.

Coughlan, P., \& Brady, E. (1996) Evolution towards integrated product development in subsidiaries of multinational enterprises. International Journal of Technology Management, 12(7/8), 733-747.

Croisier, B., (1998) The governance of external research: empirical test of some transaction-cost related factors. $R \& D$ Management, 28(4), 289-298. 
Cusumano, M. A., \& Elenkov, D., (1994) Linking international technology transfer with strategy and management: A literature commentary. Research Policy, 23, 195-215.

Dalton, D., and Serapio, M., (1995) Globalizing Industrial Research and Development. US Department of Commerce, Office of Technology Policy.

De Meyer, A., and Mizushima, A., (1989) Global R\&D Management, R\&D Management, 19, $135-146$.

Dierickx, I., \& Cool, K., (1989) Asset stock accumulation and sustainability of competitive advantage. Management Science, 35, 1504-1511.

Doz, Y. L., and Prahalad, C. K., (1991) Managing DMNC's: a search for a new paradigm. Strategic Management Journal, 12, 145-164.

Dussauge, P., Hart, S., \& Ramanantsoa, B., (1994) Strategic Technology Management. New York: John Wiley \& Sons.

Duysters, G., and Hagedoorn, J., (1998) The effect of core competence building on firm performance in a global, high-technology industry. Presented at The Academy of Management 1998 Meeting, San Diego.

Field, R., \& House, R. (1990) A test of the Vroom-Yetton model using manager and subordinate reports. Journal of Applied Psychology, 75, 362-366.

Florida, R., (1997) The globalization of R\&D: Results of a survey of foreign-affiliated R\&D laboratories in the USA. Research Policy, 26, 85-103.

Gassmann, O., \& von Zedtwitz, M., (1998) Organization of industrial R\&D on a global scale. $R \& D$ Management, 28(3), 147-161. 
Gates, S., (1995) The changing Global Role of the Research and Development Function. The Conference Board.

Granstrand, O., Hakanson, L., and Sjolander, S. (Eds.) (1992) Internationalization of $R \& D$ and Technology. New York, John Wiley and Sons.

Hakanson, L. (1990) International decentralization of R\&D - the organizational challenges. In Bartlett, C. A., Doz, Y. L., \& Hedlund, G. (Eds.) Managing the Global Firm. New York: Routledge.

Hakanson, L., \& Nobel, R. (1993a) Foreign research and development in Swedish multinationals. Research Policy, 22, 373-396.

Hakanson, L., \& Nobel, R. (1993b) Determinants of foreign R\&D in Swedish multinationals. Research Policy, 22, 397-411.

Harpaz, I., and Meshoulman, I., (1997) Intraorganizational power in high technology organizations. The Journal of High Technology Management Research, 8(1), 107-128.

Harris, R. C., Insinga, R. C., Morone, J., and Werle, M. J., (1996) The virtual R\&D laboratory. Research-Technology Management, March/April, 32-36.

Henderson, R., \& Cockburn, I., (1994) Measuring competence? Exploring firm effects in pharmaceutical research. Strategic Management Journal, 15, 63-84.

Hewitt, G. (1980) Research and development performed abroad by US manufacturing multinationals. Kyklos, 33, 308-326.

Hood, N., \& Young, S. (1982) US multinational R\&D: corporate strategies and policy implications for the UK. Multinational Business, Vol. 2, 10-23. 
Inkpen, A. C., and Beamish, P. W., (1997) Knowledge, bargaining power and the instability of international joint ventures. Academy of Management Review, 22(1), 177-202.

Kenney, M., \& Florida, R., (1994) The organization and geography of Japanese R\&D:

Results from a survey of Japanese electronics and biotechnology firms. Research Policy, $23,305-323$.

Kuemmerle, W., (1997) Building effective R\&D capabilities abroad. Harvard Business Review, March-April, 61-70.

Kuemmerle, W., (1998) Exploitation in foreign environments: an investigation into foreign direct investment in R\&D multinationals. Presented at The Academy of Management 1998 Meeting, San Diego.

Malnight, T. W. (1995) Globalization of an ethnocentric firm. Strategic Management Journal, 16, 119-141.

Malnight, T. W. (1996) The transition from decentralized to network-based structures: An evolutionary perspective. Journal of International Business Studies, 27(1), 43-65.

Medcof, J. W., (1997) A taxonomy of internationally dispersed technology units and its application to management issues. $R \& D$ Management, 27(4), 301-318.

Medcof, J. W., (1998) Resource based strategy and managerial power in networks of internationally dispersed technology units. Presented at The Academy of Management 1998 Meeting, San Diego.

Methe, D. T., and Yoshihara, H., (1998) Organizational learning and compressed experience in Japanese multinational enterprise in overseas subsidiary R\&D. Presented at The Academy of Management 1998 Meeting, San Diego. 
Mitchell, G. R., (1992) “The Changing Agenda for Research Management.” ResearchTechnology Management, Sept-Oct, 13-21.

Nicholson, G. C. (1994) How 3M manages its global laboratory network. Research-Technology Management, 21-24.

Nobel, R., and Birkinshaw, J., (1998) Innovation in multinational corporations: control and communication patterns in international R\&D operations. Strategic Management Journal, 19, 479-496.

Oliver, C., (1991) Strategic responses to institutional processes. Academy of Management Review, 16(1), 145-179.

Ohba, S., (1996) Critical issues related to international R\&D programs. IEEE Transactions on Engineering Management, 43(1), 78-87.

Pasewark, W., \& Strawser, J., (1994) Subordinate participation in audit budgeting decisions: a comparison of decisions influenced by organizational factors to decisions conforming to the Vroom-Jago model. Decision Sciences, 25, 281-299.

Pearce, R. D., (1989) The Internationalization of Research and Development by Multinational Enterprises. St. Martin's Press, new York.

Pearce, R. D., \& Singh, S., (1992a) Internationalization of research and development among the world's leading enterprises. In Granstrand, O., Hakanson, L., \& Sjolander, S., Technology Management and International Business. Chichester: John Wiley \& Sons.

Pearce, R. D., \& Singh, S., (1992b) Globalizing Research and Development. London: MacMillan. 
Pearce, R. J., (1997) Toward understanding joint venture performance and survival: a bargaining and influence approach to transaction cost theory. Academy of Management Review, 22(1), 203-225.

Pearson, A., Brockhoff, K., \& von Boehmer, A. (1993) Decision Parameters in global R\&D management. R\&D Management, 23(3), 249-262.

Penner-Hahn, J. D., (1998) Firm and environmental influences on the mode and sequence of foreign R\&D activities. Strategic Management Journal, 19, 149-168.

Peteraf, M. A., (1993) The cornerstones of competitive advantage: a resource-based view. Strategic Management Journal, 14, 179-191.

Pfeffer, J., and Salancik, G. R., (1978) The External Control of Organizations. New York: Harper \& Row.

Ransley, D. L., \& Rogers, J. L. (1994) A consensus on best R\&D practices. Research Technology Management, March-April, 19-26.

Reger, G., (1999) How R\&D is coordinated in Japanese and European multinationals. $R \& D$ Management, 29(1), 71-88.

Rhyne, L. C., \& Teagarden, M. B., (1995) International technology-based competitive strategy: A literature review and integrative model, The Journal of High Technology Management Research, 6(2), 157-178.

Ronstadt, R. C. (1977) Research and Development Abroad by US Multinationals. New York: Praeger Books. 
Ronstadt, R. C. (1978) International R\&D: The establishment and evolution of research and development abroad by seven US multinationals. Journal of International Business Studies, 9, 7-24.

Rowley, T. J., (1997) Moving beyond dyadic ties: a network theory of stakeholder influences. Academy of Management Review, 22(4), 887-910.

Rumelt, R. P., (1984) Toward a strategic theory of the firm. In R. Lamb (ed.), Competitive Strategic Management. Englewood Cliffs, NJ: Prentice Hall, 556-570.

Schilling, M. A., (1998) Technological lockout: An integrative model of the economic and strategic factors driving technology success and failure. Academy of Management Review, 23(2), 267-284.

Stock, G. N., Greis, N. P., \& Dibner, M. D. (1996) Parent-subsidiary communication in international biotechnology R\&D, IEEE Transactions on Engineering Management, 43(1), $56-68$.

Taggart, J. H., (1998) determinants of increasing R\&D complexity in affiliates of manufacturing multinational corporations in the UK. R\&D Management, 28(2), 101-110.

Teece, D. J., Pisano, G., and Shuen, A., (1997) Dynamic capabilities and strategic management. Strategic Management Journal, 18(7), 509-533.

Toyama, R., \& Methe, D. T., (1997) International R\&D and technological competence of the firm: How firms create heterogenous resources. Presented at the Annual Convention of the Academy of Management, Boston.

Vroom, V., \& Jago, A., (1988) The New Leadership: Managing Participation in Organizations. Englewood Cliffs, NJ: Prentice Hall. 
Vroom, V., \& Yetton, P., (1973) Leadership and Decision-Making. Pittsburgh: University of Pittsburgh Press.

Wernerfelt, B., (1984) A resource based view of the firm. Strategic Management Journal, 5, 171-180.

Wernerfelt, B. (1995) The resource based view of the firm: Ten years later. Strategic Management Journal, 16, 171-174.

Williamson, O. E., (1975) Markets and Hierarchies: Analysis and Anti-Trust Implications: A Study in the Economics of Internal Organization. New York: The Free Press.

Williamson, O. E., (1985) The Economic Institutions of Capitalism. Firms, Markets, Relational Contracting. London: The Free Press.

Yan, A., and Gray, B., (1994) Bargaining power, management control, and performance in United States-China joint ventures: a comparative case study. Academy of Management Journal, $37(6), 1478-1517$.

Zander, I., (1997) Technological diversification in the multinational corporation - historical evolution and future prospects. Research Policy, 26, 209-227. 


\section{Table 1}

\section{Definitions of Extra-National Technology Unit Types}

Local Research Unit. Discovers new platforms of scientific knowledge through collaborations, if any, with other technology units in its host country.

Local Development Unit. Creates new products and processes through collaboration with marketing and manufacturing and, perhaps, other technology units, in its host country.

Local Marketing Support Unit. Adapts already established product technology to the needs of particular customers and/or helps customers use those applications, through collaboration with marketing and, perhaps, other technology units, in its host country.

Local Manufacturing Support Unit. Adapts existing manufacturing processes to some particular condition through collaboration with manufacturing and, perhaps, other technology units, located in its host country.

International Research Unit. Discovers new platforms of scientific knowledge through collaboration with other technology units, at least one of which is located outside of its host country.

International Development Unit. Creates new products and processes through collaboration with marketing and manufacturing units and, perhaps, other technology units, at least one of which is located outside its host country.

International Marketing Support Unit. Adapts already established product technology to the needs of particular customers and/or helps customers use those applications, through collaboration with marketing and, perhaps, other technology units, at least one of which is outside of its host country.

International Manufacturing Support Unit. Adapts existing manufacturing processes to some particular condition through collaboration with manufacturing and, perhaps, other technology units, at least one of which is located outside its host country.

From Medcof (1997) 
INNSSREERENUEE HD

45. . 6657 no. 95 
The activities of the Management of Innovation and New Technology Research Centre are generously supported by:

- The DeGroote family

- DuPont Canada Inc

- Nórtel

- Royal Bank

- The Society of Management Accountants of Ontario

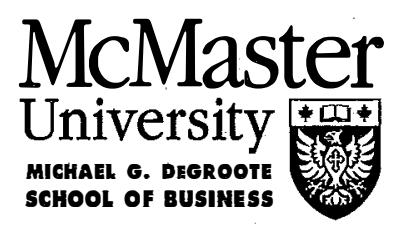

INFORMATION...

For information about the Management of Innovation and New Technology Research Centre or innovation research activities at the Michael G. DeGroote School of Business:

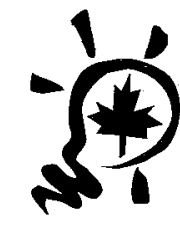

Director; Dr. C. K. Bart, Ph.D., C.A.

MINT - Research Centre

Michael G. DeGroote School of Business

McMaster University, 1280 Main St. W.

Hamilton ON Canada L8S 4M4

Phone: 905-525-9140, Ext. 24105

Fax: 905-521-8995

email: mint@mcmaster.ca

www: http://mint.mcmaster.ca/

*Management of Innovation and New Technology Research Centre (MINT) is an official mark of the

Michael G. DeGroote School of Business,

McMaster University. 